\title{
Differences in the mycoflora of dry-fermented sausages casings before and after six months
} of refrigerated storage

\author{
M. Zadravec, T. Lešić, I. Perković, Ž. Jakopović, N. Vahčić, V. Jaki Tkalec, \\ T. Dujić and J. Pleadin*
}

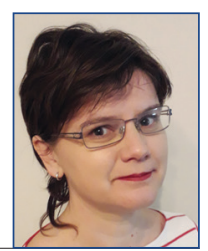

\begin{abstract}
During the curing period of dry-fermented sausages, the surface mycoflora changes according to the environmental conditions and intrinsic factors, such as nutrient content, water activity, $\mathrm{pH}$ value and the presence of antimicrobial substances (starter cultures). In this study, 25 samples of dry-fermented sausages from Croatian family small holdings were examined, the casings peeled off and examined for mycobiota before and after six months of refrigerated storage in plastic bags, at $+4{ }^{\circ} \mathrm{C}$ in darkness, at a low humidity and evaporation rate. For mycobiota identification, traditional (macroscopic and microscopic) and molecular (Polymerase Chain Reaction, PCR) methods were combined. At the beginning
\end{abstract}

of the study (after sausage curing), the prevalent isolated species were from the genera Penicillium (74\%), Aspergillus $14 \%$ and Mucor (12\%). After the six-month period, a different mould structure was observed, with the dominant isolation of Aspergillus genus (64\%), followed by the genera Penicillium (34\%) and Mucor (2\%). In comparison with the literature data, it can be concluded that the casing mycoflora on dry-fermented sausages stored in the refrigerator changed in the same way as if they not been refrigerated, though the process of mycoflora change was slower with refrigeration.

Key words: mycoflora; surface moulds; dryfermented sausages; casings; refrigerated storage

\section{Introduction}

During curing, the surface of dryfermented sausages becomes overgrown with moulds whose spores originate

mostly from the curing environment. The presence of moulds on the surface of these products contributes to the development

Manuela ZADRAVEC, DVM, PhD, Scientific Associate, Tina LEŠIĆ, BSc, PhD Student, Senior Associate, Jelka PLEADIN*, BSc, PhD, Scientific Advisor in Tenure, Associate Professor (Corresponding author, e-mail: pleadin@veinst.hr), Croatian Veterinary Institute, Zagreb, Croatia; Irena PERKOVIĆ, BSc, PhD, Postdoctoral Researcher, Croatian Veterinary Institute, Veterinary Department Vinkovci, Croatia; Željko JAKOPOVIĆ, BSc, PhD Student, Nada VAHČIĆ, BSc, PhD, Full Professor, Faculty of Food Technology and Biotechnology University of Zagreb, Zagreb, Croatia; Vesna JAKI TKALEC, DVM, PhD, Scientific Associate, Croatian Veterinary Institute, Veterinary Department Križevci, Križevci, Croatia; Tomislav DUJIĆ, DVM, Professional Associate, Croatian Veterinary Institute, Veterinary Department Split, Split, Croatia 
of the positive characteristics typical of the final products, since they retain moisture and contribute to the degradation of fat and proteins due to their lipolytic and proteolytic enzymatic activities (Toldra, 1998; Ockerman et al., 2000; Bruna et al., 2003). Moreover, the presence of these moulds results in anti-oxidising effects, contributes to better colour and sensory characteristics, prevents excessive surface drying and protects against pathogenic microorganisms (Scolari et al., 2003; Ludemann et al., 2004). However, under adverse environmental conditions, certain mould species can produce mycotoxins, which have carcinogenic, immunologic and allergic effects, and are particularly relevant in the case of food consumed by humans (Comi and Lacumin, 2013; Pleadin et al., 2015a; Zadravec et al., 2019). The negative effects of moulds on the appearance, smell, taste and nutritional value of dryfermented meat products can be caused by the overgrowth of unwanted spoilage moulds (Samson et al., 2002; Scholte et al., 2002; Asefa et al., 2009; Lešić et al., 2020).

The important factors affecting mould growth on the surface of dryfermented sausages can be summarised in the following categories: (i) intrinsic factors, including nutrient content, water activity, $\mathrm{pH}$ value and the presence of antimicrobial substances (starter culture); (ii) extrinsic factors, related to the storage environment, including storage temperature, gas composition and relative humidity (Hamad, 2012). In general, moulds that cover sausage surfaces can grow at water activities in the range of $0.70-0.95$, temperature from -2 to $40{ }^{\circ} \mathrm{C}$, and in an atmosphere with $1 \% \mathrm{O}_{2}$. However, differences in these factors can have an effect on their growth dominance. Penicillium and Mucor species prefer lower temperatures for growth than Aspergillus species, and Mucor species grow at higher water activity values $\left(a_{w}>0.9\right)$ while Penicillium and
Aspergillus grow at a levels from 0.8 to 0.9 . Moreover, Aspergillus species, especially Teleomorphs (Eurotioum-type), and Mucor species can grow in an atmosphere of 1-2\% $\mathrm{O}_{2}$ (Pitt and Hotchkin, 2009; MorinSardin et al., 2016).

According to the literature (Castellari et al., 2010; Sonjak et al., 2011; Zadravec et al., 2020) the predominant mould genus to overgrow and cover the surface of sausages is Penicillium, followed by Aspergillus and Mucor. Sausages ripening in the winter period are more suitable for Penicillium and Mucor species growth, than for Aspergillus species, which prefer higher temperatures, especially teleomorphs. On the surface of dry-fermented sausages ripening over a longer period of time (up to six months), such as Kulen and Kulenova seka (traditional pepper sausages), after ripening, Aspergillus becomes predominant, followed by the Penicillium and Mucor genera (Pleadin et al., 2017; Zadravec et al., 2020).

The aim of this study was to examine the mycobiota changes of the surfaces of Croatian domestic dry-fermented sausage casings at the end of the curing period (right after production) and after six months of refrigerated storage.

\section{Materials and Methods}

\section{Samples}

A total of 25 pairs of domestic dryfermented sausages were sampled from small family holdings in central and northern Croatia. The domestic sausages were produced according to traditional recipes of pork meat of the first and the second category and fat, with the addition of table salt, sweet and hot red paprika powdered seasoning, ground pepper and garlic, and stuffed into casings (Kovačević, 2018). Prior to stuffing, the meat and fat were mechanically minced. After stuffing, the sausages underwent drying and curing over a period of two to 
two and a half months using the smoking process.

The sampled sausage pairs were peeled and one-half of each pairs was tested for mycobiota at the beginning of the study (following the end of the curing period, right after their production and sampling, without refrigerated storage), while the second half of the pair was analysed after six months of refrigerated storage in plastic bags at $4-8^{\circ} \mathrm{C}$ in darkness, at a low evaporation rate.

\section{Mould identification}

Peeled casings were placed in Petri dishes with 18\%-glycerol (DG-18, Merck, Germany) and incubated for seven days in darkness at $25 \pm 1{ }^{\circ} \mathrm{C}$. For the purpose of species identification, the identified genera were sub-cultivated in malt extract agar (MEA, Difco International) and Czapek yeast extract agar (CYA, Difco International) and incubated for seven days at $25 \pm 1{ }^{\circ} \mathrm{C}$ in darkness. The mould isolates were identified to the species level based on macroscopic and microscopic morphological traits. For the determination of the micro-morphological traits, slides were prepared from the MEA medium, using lactophenol cotton blue (LPCB) as the mounting medium. Slides were analysed under a light microscope (AX10 type, Zeiss, Germany) at 400$1000 \times$ magnification. All isolates were identified according to Pitt and Hocking, (2009) and Samson et al. (2019).

Molecular identification of the mould isolates was performed to verify the results of the traditional identification methods. Deoxyribonucleic acid (DNA) was extracted from about $100 \mu \mathrm{g}$ of mould colonies using the Dneasy Plant Mini Kit (Qiagen, Hilden, Germany) according to the manufacturer's instructions. The primers specific for beta-tubulin (benA)-Bt2a (5'- GGTAACCAAATCGGTGCTGCTTTC-3') and Bt2b (5'-ACCCTCAGTGTAGTGACCCTTGGC-3'), and for calmodulin (CaM) loci-Cmd5 (5'-
CCGAGTACAAGGARGCCTTC-3') and Cmd6 (5'-CCGATRGAGGTCATRACGTGG-3') were selected for polymerase chain reaction (PCR) amplification. Each $25 \mu \mathrm{L}-\mathrm{PCR}$ reaction mix contained 12.5 $\mu \mathrm{L} 2 \times$ PCR buffer (HotStarTaq Plus MasterMix Kit, Qiagen), $2.5 \mu \mathrm{L} 10 \times$ Coral Load, $0.4 \mu \mathrm{M}$ each primer, nuclease-free water and $1 \mu \mathrm{L}$ DNA extract. The procedure was performed under the following cycling conditions: $95^{\circ} \mathrm{C}$ for $5 \mathrm{~min}$, followed by 40 cycles at $94^{\circ} \mathrm{C}$ for $30 \mathrm{~s}, 56^{\circ} \mathrm{C}$ for $30 \mathrm{~s}, 72^{\circ} \mathrm{C}$ for $60 \mathrm{~s}$, concluding with the final extension at $72{ }^{\circ} \mathrm{C}$ for $10 \mathrm{~min}$. PCR products were checked using gel electrophoresis in 1.5\%-agarose gel stained with GelStar nucleic acid stain (Lonza, Switzerland) and visualised using UV trans-illumination. All PCR products of an adequate size were purified prior to sequencing using either an ExoSAP-IT PCR clean up reagent (Affymetrix, Santa Clara, CA, USA), or a QIAquick Gel Extraction Kit (Qiagen). Purified samples were sent to Macrogen Inc. (Amsterdam, Netherlands) for paired-end sequencing. The obtained sequences were aligned using Lasergene SeqManPro DNASTAR 13 (Madison, WI, USA). The edited sequences were compared with those available from the CBS-KNAW Fungal Biodiversity Centre database (http://www.cbs. knaw.nl) and GenBank using the BLAST algorithm (http://blast.ncbi.nlm.nih. gov/ Blast.cgi).

\section{Statistical analysis}

Statistical analysis was performed using SPSS Statistics software v. 22 (IBM, NY, USA). The statistical significance of the difference in the number of mould isolates was determined using Mann-Whitney U test, with statistical significance set at $P \leq 0.05$.

\section{Results and Discussion}

The curing time of dry-cured meat products in different ripening stages is 
correlated with the level of humidity and water activity, which directly affects the presence of mycobiota (Castellari et al., 2010). Earlier studies reported that the surface of dry-fermented sausages are predominantly overgrown by the Penicillium genus, followed by Aspergillus and Mucor, among which $P$. nalgoviense, $P$. commune and $P$. solitum are generally the most common mould species, followed by Aspergillus anamorphs, and the rarest isolated species $M$. racemosus (Asefa et al., 2009; Castellari et al., 2010; Sonjak et al., 2011; Pleadin et al., 2017; Zadravec et al., 2020).

However, the relevant literature provides no data as to the differences between mould communities on the surface of dry-fermented sausages before and after a period of refrigerated storage. The hypothesis of this study was that the mycoflora community on dry-fermented sausage casings would not change under constant conditions of darkness, low temperature $\left(4-8^{\circ} \mathrm{C}\right)$ and storage in plastic
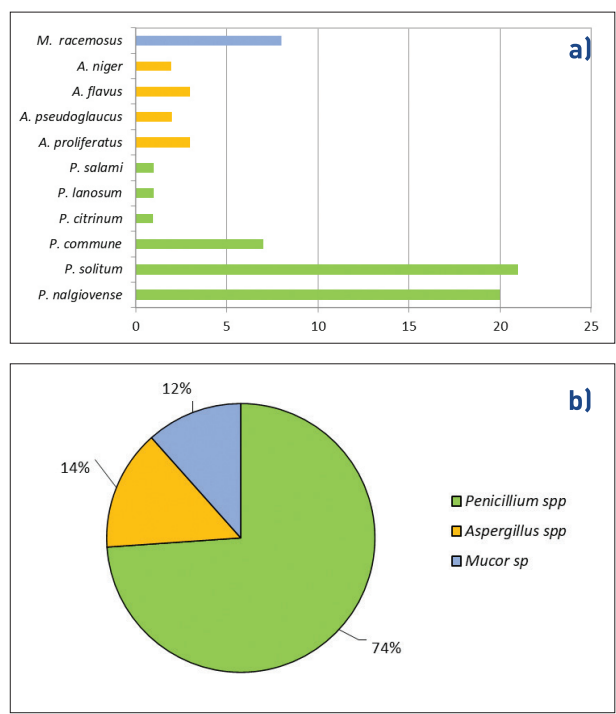

Figure 1. (a) number of isolated species from dry-fermented sausage casings, and (a) shares of each isolated genus at the beginning of the study (without refrigerated storage) bags that prevent evaporation. Isolated mould species from the surface of dryfermented sausage casings before and after six months of refrigerated storage obtained in this study are presented in Figures 1 and 2.
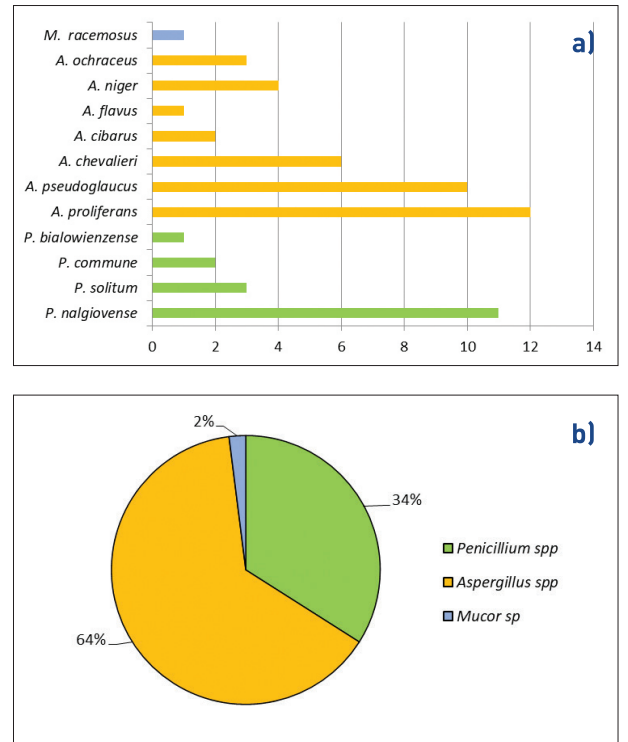

Figure 2. (a) Number of isolated species from the casings of dry-fermented sausages, (b) shares of each isolated genus after six months of refrigerated storage

No significant differences were observed in the total number of isolated species before and after the six-month refrigeration period $(P=0.976)$. At the beginning of the study, the prevalent species were from the genus Penicillium $(74 \%)$, with six species, where the most often isolated species were $P$. nalgoviensise (21) and P. solitum (20), whereas Aspergillus species accounted for a lower percentage (14\%) with only four species, A. flavus, A. niger, A. proliferans and A. pseudoglaucus. The Mucor genus was isolated in $12 \%$ of samples, with $M$. racemosus as the only species.

After the six-month refrigeration period, a different mould structure was 
obtained. The Aspergillus genus was predominant $(64 \%)$, followed by the genera Penicillium (34\%) and Mucor (2\%). The most isolated Aspergillus species were the teleomorphs $A$. cibarus, A. chevalieri, A. pseudoglaucus and A. proliferans, followed by the anamorphs $A$. ochraceus, $A$. niger and $A$. flavus. The most isolated Penicillium species were $P$. nalgoviense, $P$. commune, P. solitum and P. bialowienzense, while Mucor racemosus was the only representative of the Mucor genus. It was observed that $A$. ochraceus, A. cibarus, $A$. chevalieri and $P$. bialowienzense were not isolated at the beginning of the study, but were only identified after the refrigeration period.

The results from the beginning of the present study are in line with previous studies that also reported that the surface of dry-fermented sausages is predominantly overgrown by the Penicillium genus, followed by Aspergillus and Mucor (Castellari et al., 2010; Pleadin et al., 2017; Zadravec et al., 2020; Lešić et al., 2020). At the beginning of the study, six Penicillium species and four Aspergillus species were isolated, which is also in line with Asefa et al. (2009), Comi and Iacumin, (2013) and Pleadin et al. (2017), who reported more Penicillium than Aspergillus species on the surface of short ripening dry-cured meat products.

It is important to point out that among the Aspergillus species, the potentially mycotoxicogenic species $A$. niger (ochratoxin $\mathrm{A}$ producer) and $A$. flavus (aflatoxin $\mathrm{B}_{1}$ producer) (Pleadin et al., 2014; Pleadin et al., 2015b; Lešić et al., 2020), were isolated at the beginning of the study, as also reported in other studies (Asefa et al., 2009; Sonjak et al., 2011; Comi and Iacumin, 2013; Pleadin et al., 2017; Rodrigues et al., 2019). However, no mycotoxin-producing Penicillium species were isolated in this study. After six months of refrigerated storage, the mycotoxicogenic species $A$. ochraceus was isolated in addition to $A$. niger and $A$. flavus. It is worth mentioning that moulds produce mycotoxins when they are triggered by the environmental conditions, which could also refer to the stressful low temperatures implemented in this study (Mannaa and Kim, 2017).

The results after six months of refrigerated storage are comparable with reports by Comi and Iacumin (2013), Pleadin et al. (2017) and Zadravec et al. (2020) on the surface of dry-cured meat products ripening over a one-year period. In those studies, the most prevalent species were also Aspergillus species, especially teleomorphs, followed by Penicillium and Mucor. These observations were explained by the long period of ripening including a hot summer period, which is preferred by Aspergillus species, as opposed to Penicillium species that favour lower temperatures and a colder climate (Pitt and Hocking, 2009; Zadravec et al., 2020).

The explanation of the results presented here can be found in the fact that ascospores of Aspergillus teleomorphs (A. cibarus, A. chevaliery, A. pseudoglaucus, $A$. proliferans) can survive in a wide range of temperatures $\left(4-43^{\circ} \mathrm{C}\right)$, and a very low water activity (0.71) for up to 120 days. Despite the fact that Penicillium spores remain vital at lower temperatures (even under $0{ }^{\circ} \mathrm{C}$ ) than Aspergillus spores, Penicillium species require a higher water activity for spore vitality (0.8) (Pitt and Hocking, 2009). Mucor spores are vital at low temperatures, even at $-4{ }^{\circ} \mathrm{C}$, but require a higher water activity of 0.86 (Pitt and Hocking, 2009; Marin-Sardin et al., 2016). Additionally, Aspergillus species, especially teleomorphs, $P$. solitum, $P$. commune, $P$. nalgoviensis and Mucor racemosus (isolated in the present study) remain vital in an atmosphere of 1-2\% $\mathrm{O}_{2}$ (Pitt and Hockin 2009; Schrimer et al., 2020).

An interesting observation is that A. ochraceus, A. cibarus, A. chevlieri and 
$P$. bialowienzense were isolated after six months of refrigerated storage, but not at the beginning of the study. These results can be explained by the delicate nature of isolation, where primary isolation moulds overgrow the Petri dish, and some dominant moulds can overgrow others. In that case, some mould species may be overlooked during identification.

\section{Conclusions}

It has been assumed that a decrease of the temperature will stop natural processes or remedy them; however, this study refutes that claim. The mycoflora structure on dry-fermented sausages changes with the time of refrigeration just as in the natural environment. During storage, even at low temperatures, moulds use water and oxygen for survival, while water activity and oxygen concentration decreases. A similar process occurs during the ripening of dry-cured meat products, when was activity decreases over time, greatly affects mould survival on a surface. Therefore, lowering the temperature only slows but does not stop natural processes. A limitation of this study is that dry-fermented sausages were not stored whole with the filling and casing due to possible spoilage, which may have affected water activity. It can be concluded that the mycoflora would most likely have changed in the same way if the sausages had not been refrigerated, only these change would have occurred faster. Therefore, a future study should analyse the impact of refrigerated storage on the presence of mycoflora over a timeframe of months.

\section{Acknowledgement}

This work has been supported by the Croatian Science Foundation under the project "Mycotoxins in traditional Croatian meat products: molecular identification of mycotoxin-producing moulds and consumer exposure assessment" (HRZZ IP-2018-019017).

\section{References}

1. ASEFA, D. T., R. O. GJERDE, M. S. SIDHU, S. LANGSRUD, C. F. KURE, T. NESBAKKEN and I. SKAAR (2009): Moulds contaminants on Norwegian dry-cured meat products. Int. J. Food Microbiol. 128, 435-439.

2. BRUNA, J. M., E. M. HIERRO, L. DE LA HOZ, D. S. MOTTRAM, M. FERNÁNDEZ and J. A. ORDÓÑEZ (2003): Changes in selected biochemical and sensory parameters as affected by the superficial inoculation of Penicillium camemberti on dry fermented sausages. Int. J. Food Microbiol. 85, 111-125.

3. CASTELLARI, C., A. M. QUADRELLI and F. LAICH (2010): Surface mycobiota on Argentinean dry fermented sausages. Int. J. Food Microbiol. 142, 149-155.

4. COMI, G. and L. IACUMIN (2013): Ecology of moulds during the pre-ripening and ripening of San Daniele dry cured ham. Food Res. Int. 54, 1113-1119.

5. HAMAD, S. H. (2012): Factors Affecting the growth of Microorganisms in food. In: Bhat, R., A. K. Alias and G. Paliyath: Progress in food preservation. Chichester, West Sussex, United Kingdom: John Wiley \& Sons Ltd (405-427).

6. KOVAČEVIĆ, D. (2018): Chemistry and technology of hams and prosciuttos. University of J. J. Strossmayer, Faculty of food technology, Osijek.

7. LEŠIĆ, T., N. VAHĆIĆ, I. KOS, M. ZADRAVEC, B. SINČIĆ PULIĆ, T. BOGDANOVIĆ, S. PETRIČEVIĆ, E. LISTEŠ, M. ŚKRIVANKO and J. PLEADIN (2020): Characterization of traditional Croatian householdproduced dry-fermented sausages. Foods 9, 1-19.

8. LUDEMANN, V., G. POSE, M. L. POLLIO and J. SEGURA (2004): Determination of growth characteristics and lipolytic and proteolytic activities of Penicillium strains isolated from Argentinean salami. Int. J. Food Microbiol. 96, 13-18.

9. MANNAA, M. and K. D. KIM (2017): Influence of Temperature and Water Activity on Deleterious Fungi and Mycotoxin Production during Grain Storage. Mycobiology 45, 240-254.

10. MORIN-SARDIN, S., K. RIGALMA, L. COROLLER, J. L. JANY and E. COTON (2016): Effect of temperature, $\mathrm{pH}$, and water activity on Mucor spp. growth on synthetic medium, cheese analog and cheese. Food Microbiol. 56, 69-79.

11. OCKERMAN, H. W., F. J CÉSPEDES SÁNCHEZ and F. LEÓN CRESPO (2000): Influence of moulds on flavour quality of Spanish ham. J. Muscle Foods $11,247-259$

12. PITT, J. I. and A. D. HOCKING (2009): Fungi and Food Spoilage. Springer, New York, USA.

13. PLEADIN, J., A. VULIĆ, N. PERŠI, M. ŠKRIVANKO, B. CAPEK and Ž. CVETNIĆ (2014): Aflatoxin B1 occurrence in maize sampled from Croatian farms and feed factories during 2013. Food Control 40, 286-291.

14. PLEADIN, J., M. MALENICA STAVER, N. VAHČIĆ, D. KOVAČEVIĆ, S. MILONE, L. SAFTIĆ and G. SCORTICHINI (2015a): Survey of aflatoxin B1 and ochratoxin A occurrence in traditional meat products coming from Croatian households and markets. Food control 52, 71-77.

15. PLEADIN, J., D. KOVAČEVIĆ and N. PERŠI (2015b): Ochratoxin A contamination of the autochthonous dry-cured meat product "Slavonski 
Kulen" during a six-month production process. Food Control 57, 377-384.

16. PLEADIN, J., M. ZADRAVEC, D. BRNIĆ, I. PERKOVIĆ, M. ŚKRIVANKO and D. KOVAČEVIĆ (2017): Moulds and mycotoxins detected in the regional speciality fermented sausage 'slavonski kulen' during a 1-year production period. Food Addit. Contam. A. 34, 282-290.

17. RODRIGUES, P., D. SILVA, P. COSTA, L. ABRUNHOSA, A. VENÂNCIO and A. TEIXEIRA (2019): Mycobiota and mycotoxins in Portuguese pork, goat and sheep dry-cured hams. Mycotoxin Res. 35, 405-412.

18. SAMSON, R. A., E. S. HOEKSTRA, J. C. FRISVAD and O. FILTENBORG (2002): Introduction to Food and Airborne Fungi. Centraalbureau voor Schimmelcultures, Utrecht.

19. SCHIRMER, B. C. T., O. SØRHEIM, I. SKAAR and C. F. KURE (2020): The Influence of Concentrations of Carbon Dioxide and Residual Oxygen on the Growth of Meat Spoilage Moulds. J. Food Sci. Nutr. 6, 064.

20. SCHOLTE, R. P. M., R. A. SAMSON and J. DIJKSTERHUIS (2002): Spoilage fungi in the industrial processing of food. In: Samson, R. A., E. S. Hoekstra, J. C. Frisvad and O. Filtenborg: Introduction to Food- and Airborne Fungi. Centraalbureau voor Schimmelcultures, Utrecht (339-356).

21. SCOLARI, G., P. G. SARRA and P. BALDINI (2003): Mikrobiologija suhega mesa. In: Bem, Z., C. J. Adamič, B. Zlender, S. Smole Možina and L. Gašperlin: Mikrobiologija živil živalskega izvora. Biotehniška fakulteta, Odelek za živilstvo, Ljubljana. (351-362).

22. SONJAK, S., M. LIČEN, J. C. FRISVAD and N. GUNDE CIMERMAN (2011): The mycobiota of tree dry-cured meat products from Slovenia. Food Microbiol. 28, 373-376.

23. TOLDRA, F. (1998): Proteolysis and lipolysis in flavour development of dry cured meat products. Meat. Sci. 49, 101-110.

24. ZADRAVEC, M., K. MARKOV, J. FRECE, I. PERKOVIĆ, Ž. JAKOPOVIĆ, T. LEŠIĆ, M. MITAK and J. PLEADIN (2019): Toxicogenic fungi and the occurrence of mycotoxins in traditional meat products. Croat. J. Food Sci. Technol. 11, 272-282.

25. ZADRAVEC, M., N. VAHČIĆ, D. BRNIĆ, K. MARKOV, J. FRECE, R. BECK, T. LEŠIĆ and J. PLEADIN (2020): A study of surface moulds any mycotoxins in Croatian traditional dry-cured meat products. Int. J. Food Microbiol. 317, 108459.

\section{Razlike u mikoflori na ovitcima trajnih fermentiranih kobasica prije i šest mjeseci nakon skladištenja u hladnjaku}

Dr. sc. Manuela ZADRAVEC, dr. med. vet., znanstvena suradnica, Tina LEŠIĆ, mag. ing., doktorandica, viša stručna suradnica, dr. sc. Jelka PLEADIN, dipl. ing., znanstvena savjetnica u trajnom zvanju, izvanredna profesorica, Hrvatski veterinarski institut, Zagreb, Hrvatska; dr. sc. Irena PERKOVIĆ, dipl. ing., poslijedoktorandica, Hrvatski veterinarski institut, Veterinarski zavod Vinkovci, Hrvatska; Željko JAKOPOVIĆ, dipl. ing., doktorand, dr. sc. Nada VAHČIĆ, dipl. ing., redovita profesorica, Prehrambeno-biotehnološki fakultet Sveučilišta u Zagrebu, Zagreb, Hrvatska; dr. sc. Vesna JAKI TKALEC, dr. med. vet., znanstvena suradnica, Hrvatski veterinarski institut, Veterinarski zavod Križevci, Križevci, Hrvatska; Tomislav DUJIĆ, dr. med. vet., stručni suradnik, Hrvatski veterinarski institut, Veterinarski zavod Split, Split, Hrvatska

Tijekom razdoblja zrenja trajnih fermentiranih kobasica mikoflora koja obrasta i prekriva njihovu površinu mijenja se u ovisnosti o uvjetima okoliša i "unutarnjim čimbenicima", koji uključuju sadržaj hranjivih sastojaka, aktivitet vode, $\mathrm{pH}$ vrijednost i prisutnost antimikrobnih tvari (starter kulture). U ovom je istraživanju uzorkovano dvadeset i pet parova trajnih fermentiranih kobasica s malih hrvatskih obiteljskih poljoprivrednih gospodarstava, odljušten je njihov ovitak te je ispitivana mikoflora prije i nakon skladištenja u hladnjaku tijekom šest mjeseci, u plastičnim vrećicama, na $+4{ }^{\circ} \mathrm{C}$, u tami, pri maloj vlažnosti i brzini isparavanja. $\mathrm{Za}$ identifikaciju plijesni kombinirane su tradicionalne (makroskopske i mikroskopske) i molekularne (lančana reakcija polimeraze,
PCR) metode. Na početku istraživanja (nakon sazrijevanja i uzimanja uzoraka kobasica) prevladavale su izolirane vrste iz roda Penicillium (74\%), Aspergillus $14 \%$ i Mucor (12\%). Nakon razdoblja od šest mjeseci uočena je drugačija struktura plijesni, pri čemu je pretežno izoliran rod Aspergillus (64\%), a zatim Penicillium (34\%) i Mucor (2\%). Sagledavajući literaturne podatke može se zaključiti da se mikoflora na ovitcima trajnih fermentiranih kobasica pohranjenih $\mathrm{u}$ hladnjaku mijenjala na isti način kao što bi se i mijenjala bez pohranjene u hladnjaku, jedino što bi proces promjena mikoflore vremenski trajao kraće.

Ključne riječi: mikoflora, površinske plijesni, trajne fermentirane kobasice, ovitci, pohrana u hladnjaku 